\title{
Complex fibroadenoma: bibliometric literature review and presentation of a clinical case
}

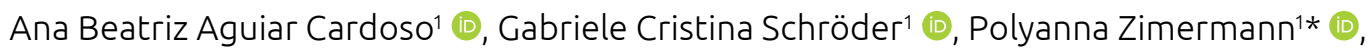 \\ Thiago Santos Lima Almendra² (1), Antonione Santos Bezerra Pinto ${ }^{10}$
}

\section{ABSTRACT}

Fibroadenomas (FAs) are benign fibro-epithelial tumours of the breast characterized by being biphasic and having stromal and epithelial components. It is estimated that FAs affect more than 20 percent of the general population aged 16-40 years old. Complex FAs are a sub-type of fibroadenoma presenting one or more pathological characteristics, such as epithelial calcifications, apocrine metaplasias, sclerosing adenoma and cysts larger than $3 \mathrm{~mm}$. According to studies elsewhere, women with complex FAs are 3.1 times more likely to develop breast cancer. The objective of the present study was to map the scientific production of articles on complex FA in the international literature. The ISI Web of Knowledge (Web of Science), one of the main scientific databases in the world, was searched with the following terms: ("complex" and "fibroadenoma") or ("fibroadenoma" and "complex"). Only articles published between 1981 and 2019 were considered for a bibliometric review, in which 160 articles from 126 different periodicals were identified after using refinement filters. Moreover, a clinical case was also discussed based on the patient's medical record and interview.

KEYWORDS: diagnosis; fibroadenoma; therapeutics.

\section{INTRODUCTION}

Fibroadenomas (FAs) are benign fibro-epithelial tumours of the breast, ${ }^{1}$ characterized by being biphasic and having stromal and epithelial components. ${ }^{2}$ They develop in the lobular unit of the terminal duct ${ }^{3}$ and affect mainly adolescent girls and adult young women. FAs occur with high incidence in the second and third decades of life, ${ }^{4}$ although they may also occur at any age, ${ }^{2}$

FAs are asymptomatic in about $25 \%$ of cases, multiple in $13 \%-15 \%$ and bilateral in $10 \%-15 \%$ of them, being more common in the left breast and predominantly located in the superiorlateral quadrants. Estimates believe that more than $20 \%$ of the female population aged 16-40 years old is affected, but a higher number confirming that nodules are often asymptomatic should be expected to be seen.$^{5}$

FAs are stimulated by estrogen, progesterone, gestation and lactation, and become atrophied in the menopause period ${ }^{6}$. In most cases, they present as mammary masses not greater than $3-4 \mathrm{~cm}$. In addition to its usual form of presentation, FAs may uncommonly occur in the juvenile, giant, extra-mammary and complex forms. ${ }^{7}$
The pathogenesis of FA is still not clear. However, an association with high expression of the B-cell lymphoma gene (BCL-2) in epithelial cells of FA was discovered. In addition, there is also a relation with the mutation in the mediator complex subunit 12 gene (MED12), located on the chromosome $\mathrm{X}$ in stroma cells. ${ }^{5}$

Complex FAs are a sub-type of fibroadenoma, and they have one or more pathological characteristics. Both complex and simple FAs frequently show single nodules in parallel to the skin surface. ${ }^{3}$

As to size, complex FAs are smaller than simple ones. ${ }^{6}$ This occurs because FAs tend to recede with age, lose cellularity and acquire complex histopathological features. ${ }^{3}$

According to a study, women with complex FAs are 3.1 times more likely to develop invasive breast cancer compared to the general population. ${ }^{1,6}$ This risk remains high for at least 20 years after diagnosis, ${ }^{1}$ which leads to the need of following up the patient longitudinally.

Treating of FAs can range depending on the patient's age and nodule's size. Because of this, the present study is aimed at conducting a bibliometric review of the literature on complex

${ }^{1}$ Faculdade de Ciências Humanas, Exatas e da Saúde do Piauí/Instituto de Educação Superior do Vale do Parnaíba - Parnaíba (PI), Brazil. ¿Universidade Federal do Delta do Parnaíba - Parnaíba (PI), Brazil.

*Corresponding author: polyanna_zimermann@hotmail.com

Conflict of interests: nothing to declare.

Received on: 08/04/2020. Accepted on: 09/30/2020. 
FA, in addition to showing a clinical case based on imaging and anatomopathological characteristics of the disease.

\section{METHODS}

The present study is a bibliometric review aimed at quantifying the written communication process by using statistics and mathematics so that a quantitative basis can be provided to date back to documentary information. ${ }^{8}$ In addition, the scientific production on complex FA in international literature was also mapped. The ISI Web of Knowledge (Web of Science), one of the main scientific databases in the world, was searched with the following terms: ("complex" and "fibroadenoma") or ("fibroadenoma" and "complex"). Only articles published between 1981 and 2019 were included for a bibliometric literature review on the theme. The methodology used refinement filters to identify related articles on the ISI Web of Knowledge database, in which 160 ones were from 126 different journals. Only articles and reviews were included, whereas editorials, book chapters, and event publications were excluded. The main results of this analysis were the number of studies in progress, the top journals on the theme, and the most cited articles.

The present study also described a clinical case report based on the patient's medical record and interview, including diagnostic methods and treatments used. The patient was asked to sign an informed consent form, according to the Brazilian norms and regulations on human research, including Resolutions No. 466/12 and 510/16 of the National Health Council (CNS). This study was approved by the Research Ethics Committee of Instituto Tocantinense Presidente Antonio Carlos (UNITPAC), according to Protocol No. 3838142.

\section{RESULTS}

After the bibliographic review on the ISI Web of Knowledge (Web of Science) database, a total of 160 articles on fibroadenoma was identified. These articles were published in 126 different journals indexed on this database and written by 911 authors, linked to 287 institutions located in 45 countries. All these articles used 4,157 references, approximately 26 each, on average. Table 1 lists the results below.

Table 1. General results of bibliometric review (1981-2019).

\begin{tabular}{l|c}
\hline Bibliometric data & Quantity \\
\hline Publications (articles) & 160 \\
\hline Indexed journals & 126 \\
\hline Authors & 911 \\
\hline Instituitions (links of authors) & 287 \\
\hline Countries & 45 \\
\hline Cited references & 4,157 \\
\hline
\end{tabular}

Although this bibliographic review has been performed for the 1945-2019 period (full years only), the first article was only published in 1981 and publications on the theme increased from 1991 onwards (Figure 1 and Table 2). Considering all the years in which there was a publication, approximately five articles were published per year, on average.

Table 3 shows the journals with the highest quantity of published articles, highlighting the Journal of Ultrasound in Medicine. The other journals that ranked from $9^{\text {th }}$ to $21^{\text {st }}$ had two articles; and those that ranked from $22^{\text {nd }}$ onwards had only one article.

Table 4 shows the ranking of authors with the highest number of published articles and their total citations. The other authors that ranked from $8^{\text {th }}$ to $62^{\text {nd }}$ had two articles published, whereas those that ranked from $63^{\text {rd }}$ onwards had only one.

As to the number of articles published per country and according to each author's institution (Table 5), the United States leads the list of research as they account for $30 \%$ of the total number of publications.

Of the 160 articles reviewed, 31 were cited at least 40 times and selected according to the parameters of the software VOSviewer.

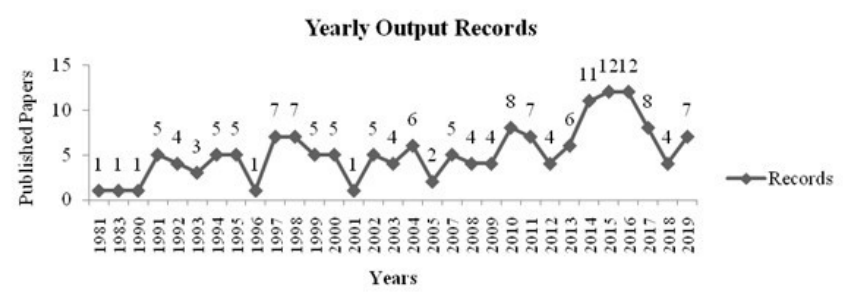

Figure 1. Yearly records of published articles (1981-2019).

Table 2. Yearly records of published articles (1981-2019).

\begin{tabular}{c|c|c|c|c|c} 
Years & Articles & Citations & Year & Articles & Citations \\
\hline 1981 & 1 & 66 & 2004 & 6 & 186 \\
\hline 1983 & 1 & 4 & 2005 & 2 & 81 \\
\hline 1990 & 1 & 170 & 2007 & 5 & 723 \\
\hline 1991 & 5 & 243 & 2008 & 4 & 69 \\
\hline 1992 & 4 & 203 & 2009 & 4 & 125 \\
\hline 1993 & 3 & 118 & 2010 & 8 & 157 \\
\hline 1994 & 5 & 529 & 2011 & 7 & 115 \\
\hline 1995 & 5 & 206 & 2012 & 4 & 28 \\
\hline 1996 & 1 & 24 & 2013 & 6 & 41 \\
\hline 1997 & 7 & 131 & 2014 & 11 & 221 \\
\hline 1998 & 7 & 155 & 2015 & 12 & 179 \\
\hline 1999 & 5 & 83 & 2016 & 12 & 171 \\
\hline 2000 & 5 & 189 & 2017 & 8 & 17 \\
\hline 2001 & 1 & 64 & 2018 & 4 & 2 \\
\hline 2002 & 5 & 130 & 2019 & 7 & 9 \\
\hline 2003 & 4 & 202 & & & \\
\hline & & & & &
\end{tabular}


Table 3. Top journals with the most articles published (1981-2018).

\begin{tabular}{l|c|c|c}
\hline Journals & $\begin{array}{c}\text { Number } \\
\text { of articles }\end{array}$ & Citations & $\begin{array}{c}\text { Citations/ } \\
\text { Quantity }\end{array}$ \\
\hline $\begin{array}{l}\text { Journal of Ultrasound in } \\
\text { Medicine }\end{array}$ & 5 & 52 & 10.4 \\
\hline $\begin{array}{l}\text { Breast Cancer Research } \\
\text { and Treatment }\end{array}$ & 4 & 71 & 17.75 \\
\hline $\begin{array}{l}\text { Histopathology } \\
\begin{array}{l}\text { International Journal of } \\
\text { Cancer }\end{array}\end{array}$ & 4 & 145 & 36.25 \\
\hline $\begin{array}{l}\text { American Journal of } \\
\text { Surgical Pathology }\end{array}$ & 3 & 135 & 55 \\
\hline $\begin{array}{l}\text { Asian Pacific Journal of } \\
\text { Cancer Prevention }\end{array}$ & 3 & 22 & 7.33 \\
\hline $\begin{array}{l}\text { Journal of Pathology } \\
\text { Pediatric Radiology }\end{array}$ & 3 & 254 & 84.67 \\
\hline
\end{tabular}

Table 4. Authors with the most articles published (1980-2018).

\begin{tabular}{|c|c|c|c|c|}
\hline Authors & Articles & Citations & $\begin{array}{l}\text { Affiliation } \\
\quad \text { (link } \\
\text { instituitions) }\end{array}$ & Country \\
\hline Kim SJ & 4 & 7 & $\begin{array}{l}\text { Myongji } \\
\text { Hospital }\end{array}$ & $\begin{array}{l}\text { South } \\
\text { Korea }\end{array}$ \\
\hline Reis JS & 4 & 169 & $\begin{array}{c}\text { Memorial } \\
\text { Sloan-Kettering } \\
\text { Cancer Center }\end{array}$ & USA \\
\hline Tan PH & 4 & 194 & $\begin{array}{c}\text { Singapore } \\
\text { General } \\
\text { Hospital }\end{array}$ & Singapore \\
\hline Brogi E & 3 & 133 & $\begin{array}{c}\text { Memorial } \\
\text { Sloan-Kettering } \\
\text { Cancer Center }\end{array}$ & USA \\
\hline Carney JÁ & 3 & 135 & $\begin{array}{c}\text { Georgetown } \\
\text { University }\end{array}$ & USA \\
\hline $\begin{array}{l}\text { de las } \\
\text { Mulas JM }\end{array}$ & 3 & 42 & $\begin{array}{c}\text { National } \\
\text { University of } \\
\text { Cordoba }\end{array}$ & Spain \\
\hline Millan Y & 3 & 42 & $\begin{array}{c}\text { National } \\
\text { University of } \\
\text { Cordoba }\end{array}$ & Spain \\
\hline
\end{tabular}

Table 5. Number of articles by country of origin of the authors' link instituitions.

\begin{tabular}{l|c|c} 
Country & Amount & Citations \\
USA & 47 & 2.802 \\
\hline Italy & 10 & 229 \\
\hline UnitedKingdom & 10 & 647 \\
\hline France & 8 & 147 \\
\hline Germany & 7 & 57 \\
\hline Taiwan & 7 & 60 \\
\hline Brazil & 6 & 143 \\
\hline India & 6 & 11 \\
\hline Japan & 6 & 181 \\
\hline China & 6 & 191 \\
\hline
\end{tabular}

Of these, 11 articles had citations between each other and are shown in Figure 2.

As to the most cited articles, Dupont et al., ${ }^{1}$ Lim et al. ${ }^{9}$ and Tan et al..$^{10}$ (Table 6) are highlighted.

Fibroadenoma, carcinoma, cancer, expression, and lesions were among the most cited keywords in publications (Figure 3).

\section{CASE REPORT}

A 26-year-old single black woman sought specialized medical care in October 2019 due to the presence of a nodule in her right breast for one year. There was absence of pain and phlogistic sings, but the nodule had recently grown. Clinical history revealed that the patient had no chronic disease, nor history of smoking, alcoholism or use of continuous medication. Menarche occurred at 11 years old and there was no family history of cancer. Complementary examinations were asked after the patient was clinically examined.

Ultrasonography (USG) of the breast was performed on $16^{\text {th }}$ October 2019, revealing the presence of two nodules in her right

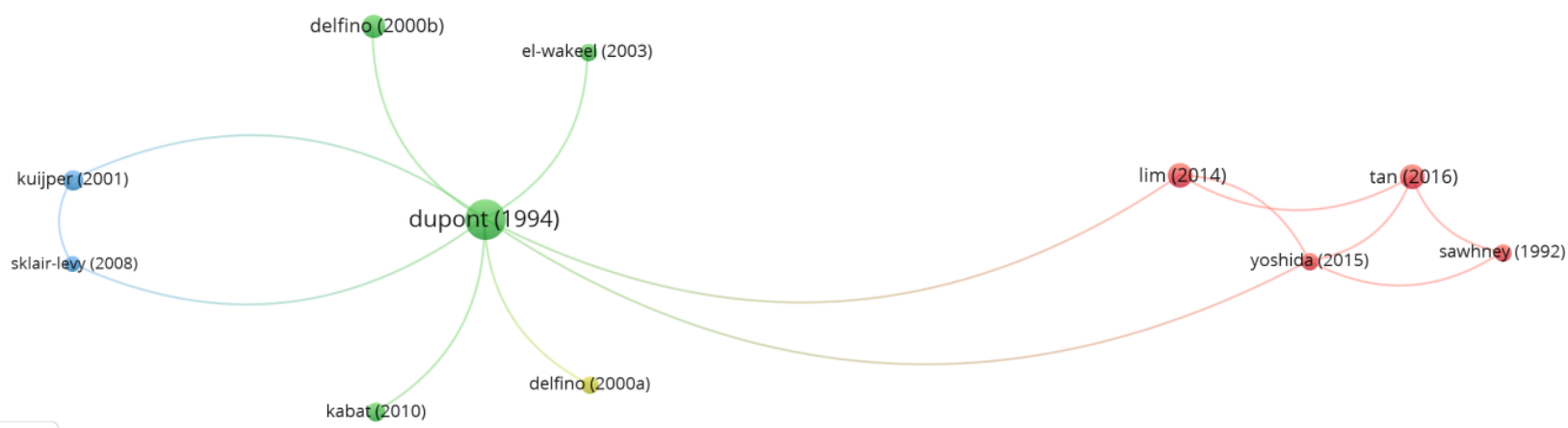

禹 vosviewer

Figure 2. Most cited and most related articles (1981-2019). 
Table 6. Most cited articles.

\begin{tabular}{|c|c|c|c|}
\hline Authors/year & Title & Source & Citations \\
\hline $\begin{array}{l}\text { Dupont et al. } \\
(1994)^{1}\end{array}$ & "Long-term risk of breast cancer in women with fibroadenoma" & $\begin{array}{c}\text { New England } \\
\text { Journal of } \\
\text { Medicine }\end{array}$ & 240 \\
\hline $\begin{array}{l}\text { Kuijper et al. } \\
(2001)^{2}\end{array}$ & "Histopathology of fibroadenoma of the breast" & $\begin{array}{c}\text { American Journal } \\
\text { of Clinical } \\
\text { Pathology }\end{array}$ & 64 \\
\hline $\begin{array}{l}\text { Sklair-Levy et al. } \\
(2008)^{6}\end{array}$ & "Incidence and management of complex fibroadenomas" & $\begin{array}{l}\text { American Journal } \\
\text { of Roentgenology }\end{array}$ & 43 \\
\hline Lim et al. (2014) & $\begin{array}{l}\text { "Exome sequencing identifies highly recurrent med12 } \\
\text { somatic mutations in breast fibroadenoma" }\end{array}$ & Nature Genetics & 91 \\
\hline Tan et al. $(2016)^{10}$ & "Phyllodes tumours of the breast: a consensus review" & Histopathology & 90 \\
\hline $\begin{array}{l}\text { Delfino et al. } \\
(2000)^{11}\end{array}$ & $\begin{array}{l}\text { "Breast cancer, passive and active cigarette smoking } \\
\text { and n-acetyltransferase } 2 \text { genotype" }\end{array}$ & Pharmacogenetics & 46 \\
\hline $\begin{array}{l}\text { Delfino et al. } \\
(2000)^{12}\end{array}$ & $\begin{array}{l}\text { "Breast cancer, heterocyclic aromatic amines } \\
\text { from meat and n-acetyltransferase } 2 \text { genotype" }\end{array}$ & Carcinogenesis & 80 \\
\hline $\begin{array}{l}\text { El-Wakeel e } \\
\text { Umpleby }(2003)^{13}\end{array}$ & "Systematic review of fibroadenoma as a risk factor for breast cancer" & Breast & 44 \\
\hline $\begin{array}{l}\text { Kabat et al. } \\
(2010)^{14}\end{array}$ & $\begin{array}{l}\text { "A multi-center prospective cohort study of benign } \\
\text { breast disease and risk of subsequent breast cancer" }\end{array}$ & $\begin{array}{l}\text { Cancer Causes \& } \\
\text { Control }\end{array}$ & 56 \\
\hline $\begin{array}{l}\text { Yoshida et al. } \\
(2015)^{15}\end{array}$ & "Frequent med12 mutations in phyllodes tumours of the breast" & $\begin{array}{l}\text { British Journal of } \\
\text { Cancer }\end{array}$ & 47 \\
\hline $\begin{array}{l}\text { Sawhney et al. } \\
(1992)^{16}\end{array}$ & $\begin{array}{l}\text { "Epithelial--stromal interactions in tumors. } \\
\text { A morphologic study of fibroepithelial tumors of the breast" }\end{array}$ & Cancer & \\
\hline
\end{tabular}

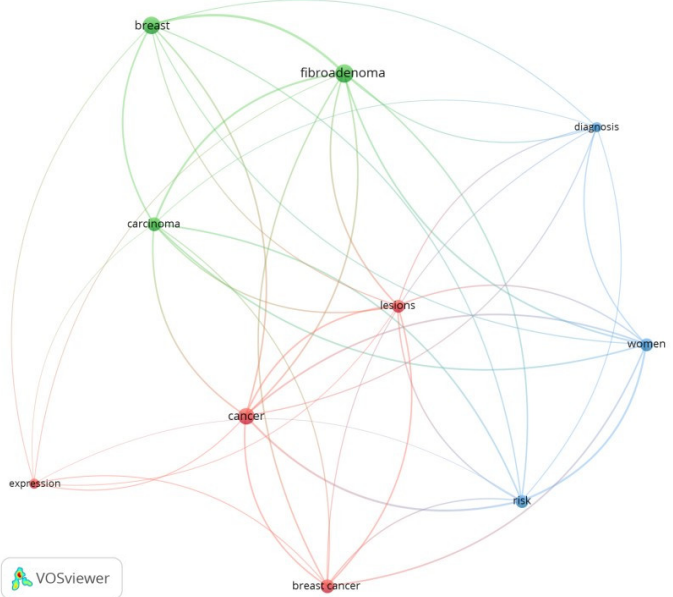

Figure 3. Co-occurrence of the most cited and most related keywords (1981-2019).

breast. One nodule was oval-shaped, circumscribed, hypoechogenic, measuring $3.1 \times 1.9 \times 2.9 \mathrm{~cm}$, located in parallel to the skin surface at the junction of the upper quadrants of the breast and in 12-hour position (Figure 4). The other nodule was oval-shaped, micro-lobulated, hypoechogenic, measuring $3.0 \times 1.7 \times 2.6 \mathrm{~cm}$ located at the lower-lateral quadrant of the breast and in 8-hour position (Figure 5). Axillarylymph nodes had usual appearance. Based on the Breast Imaging Reporting and Data System (BI-RADS) classification, examination indicated that the lesion was suspected to be highly malignant and suggested biopsy of the nodule in the 8-hour position.

Core biopsy of the micro-lobulated nodule was performed on $22^{\text {nd }}$ October 2019. Histological sections revealed the presence of benign fibro-epithelial neoplasm compatible with complex FA (Figure 6).

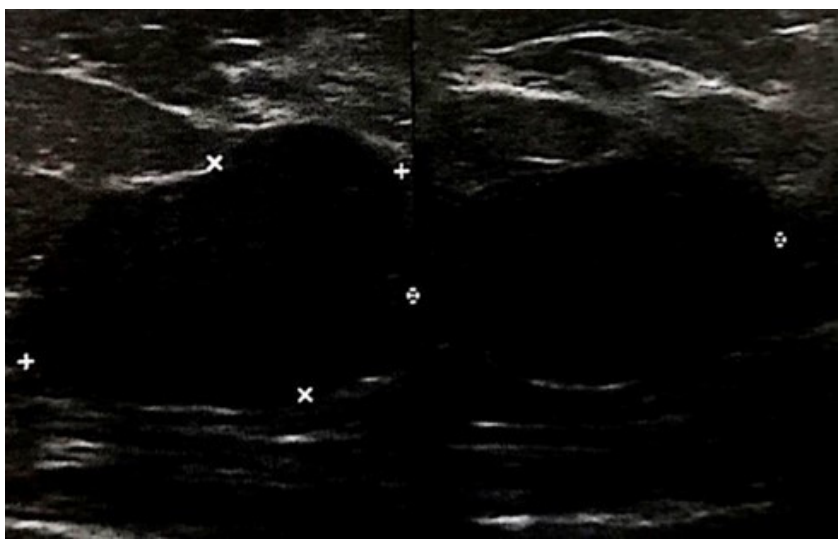

Figure 4. Ultrasonography of the right breast, showing oval-shaped, circumscribed, hypoechogenic nodule, measuring $3.1 \times 1.9 \times 2.9 \mathrm{~cm}$, located in parallel to the skin surface at the junction of the upper quadrants.

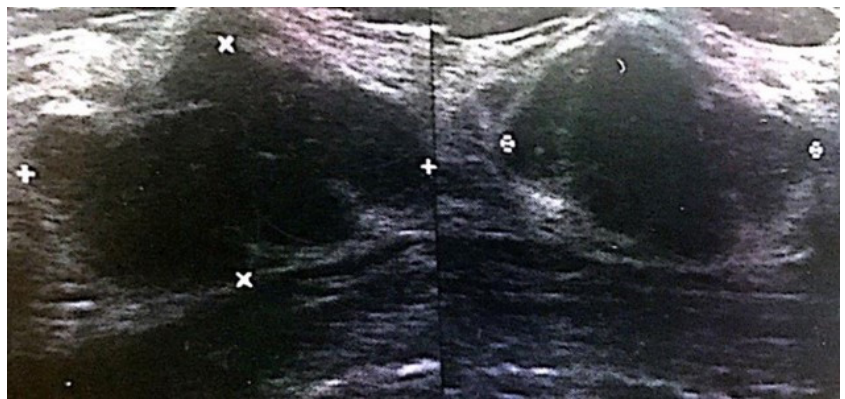

Figure 5. Ultrasonography of the right breast showing oval-shaped, circumscribed, micro-lobulated nodule, measuring $3.0 \times 1.7 \times 2.6 \mathrm{~cm}$, located at the lower-lateral quadrant. 

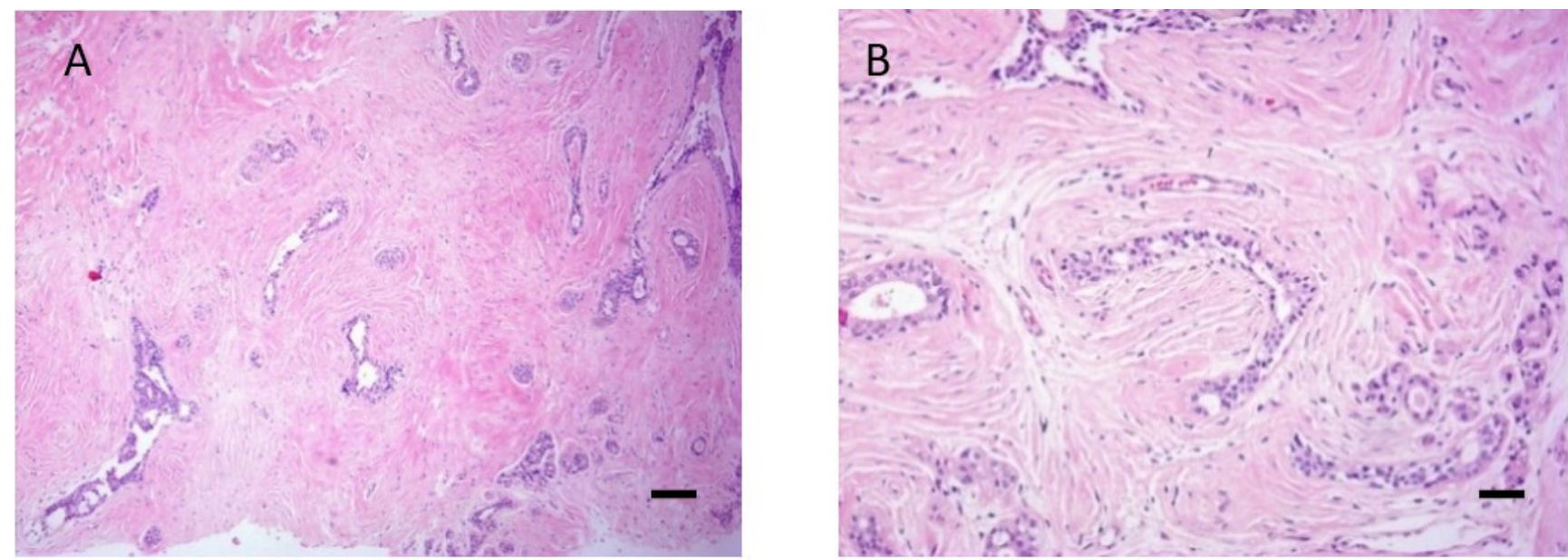

Figure 6. A (100x magnification) and B (400x magnification): Microphotograph of the nodule stained with haematoxylin \& eosin, revealing benign fibro-epithelial neoplasm, characterized by ductile proliferation with an intra-and peri-canalicular pattern and collagenized stroma.

After diagnostic confirmation, the patient was referred to an oncological surgeon for evaluation. The surgeon opted for performing two surgeries on different days, due to lack of proximity of the nodules and to avoid necrosis of the papilla with areole incision. The surgeries were held on $1^{\text {st }}$ December 2019 and $21^{\text {st }}$ January 2020. The biopsy was repeated after removal of the nodules, confirming the diagnosis of complex FA.

\section{DISCUSSION}

After the bibliographic review, high-quality articles indexed on the Web of Science database could be found, and having an overview of the scientific production in the world was possible, showing that there are only 160 studies on fibroadenoma. As to the evolution of publications per year, the first article was published in 1981, and that the number of these studies increased significantly from 1991 onwards, with five publications yearly, on average.

Most studies are published in foreign journals, highlighting the Journal of Ultrasound in Medicine, which has the highest number of published articles. As to the number of published articles by country and according to the author's institutional links, the United States leads the list of studies as they account for almost $30 \%$ of all publications. Among the authors with the most cited articles, Dupont et al., ${ }^{1}$ Lim et al. ${ }^{9}$ and Tan et al. ${ }^{10}$ are highlighted.

In the present clinical case, the patient was 26 years old, which coincided with the most affected age group, as reported in the literature. Nevertheless, one of the FAs found was located in the right breast at the junction of the upper quadrants in 12-hour position, and the other was at the lower-lateral quadrant in 8-hour position, which is not consistent with the usual findings in literature.

Complex FAs are a sub-type of fibroadenoma, presenting one or more pathological characteristics, such as epithelial calcifications, apocrine metaplasias, sclerosing adenoma, and cysts larger than $3 \mathrm{~mm}$. Among the most frequent characteristics, irregular shape, complex echo-structure with anechoic and echogenic components, including non-circumscribed contours, which can be micro-lobulated, indistinct, spiculated, and angular are mentioned. Some characteristics reported in literature coincide with those found in the patient's nodules, such as micro-lobulation (nodule in 8-hour position) and parallel orientation to the skin surface (nodule in 12-hour position), whereas others diverge, such as the presence of more than one nodule.

In the present clinical case, the patient's nodule classified as complex, based on a histopathological evaluation, which showed smaller measurements $(3.0 \times 1.7 \times 2.6 . \mathrm{cm})$ compared to those of a simple FA $(3.1 \times 1.9 \times 2.9 \mathrm{~cm})$. The volume of FAs can increase by $16 \%$ per month in women younger than 50 , whereas in older women the volume increases by $13 \%$, or $20 \%$ in all dimensions during six months in women of all ages. Although this growth does not necessarily mean a process of malignancy, surgical excision is recommended if these dimensions are exceeded. ${ }^{17}$

As to pathogenesis, there is a relation with an increased expression of the BCL-2 gene, which accounts for apoptosis prevention. ${ }^{5}$ This maintains the balance between cell proliferation and programmed cell death, which is the mechanism by which cells with damaged DNA are removed without causing any harm. ${ }^{18}$

Moreover, MED12 has been reported to be one of the most frequently mutated genes in FAs, located on chromosome Xq13.1. The high frequency of MED12 mutations in fibro-epithelial tumours suggests that it is a somatic gene leading to fibro-epithelial tumorigenesis. Mutations were reported in the exon-2 of MED12 gene, which encodes a protein interacting with proteins CDK8 (human protein kinase), CDK19, CYCC, and MED13. This protein interaction forms a complex for mediating the RNA polymerase II, which participates in the regulation of transcription and consequently in the development of FA. Besides that, codon 44 was found to be highly mutated and representing $86 \%$ of the mutations of FA. ${ }^{19}$

The management of younger patients is usually more conservative when clinical, histological, and imaging criteria, including thick-needle aspiration biopsy, suggest a benign lesion. Lesions 
characterized by BI-RADS 2 follow a screening routine, whereas those characterized by BI-RADS 3 require a six-month ultrasound followup iflesions had been ultrasonographically observed, or a mammographic follow-up iflesions had been mammographically observed. FAs with no atypical findings can be monitored with mammography or ultrasound twice a year, for two years and, then once a year. ${ }^{6}$

Performing a percutaneous biopsy is recommended to confirm the histological diagnosis if the following findings are present: inconclusive ultrasound findings (BI-RADS 4); evidence of growth trend (clinically and ultrasonographically); new palpable mass during menopause; solid mass found in a patient with risk factors (positive family risk and/or BRCA mutation); and mammography showing mass with suspicious micro-calcifications ${ }^{20}$. In this way, excisional biopsy is indicated when histopathological biopsy reveals a high-risk lesion to rule out possible malignancy.

In the present case, ultrasonography showed presence of the BI-RADS 4 lesion. In category 4, although lesions did not have the morphological characteristics typically seen in cancer, they may be malignant, thus justifying a biopsy. ${ }^{21}$ The diagnosis of complex FA was achieved after analysis of the biopsied material.

Mammography has a sensitivity of $85 \%-95 \%$ and can be used for primary diagnosis of FA, but its specificity is lower. Seen that, other diagnostic methods must be used. ${ }^{22}$ In the present case, ultrasonography was chosen because young patients present dense breasts, which makes it difficult to visualize nodules on mammogram.

Studies demonstrate that sound-elastography can be used as a complementary diagnosis to evaluate unclear breast masses, such as fibroadenomas, thus contributing to the follow-up and clinical management of patients. However, combining BI-RADS classification with elastography is needed for a more effective management. ${ }^{23}$

Treating this pathology can vary depending on the patient's age and nodule's dimensions. In general, simple removal is performed when the nodule is larger than $2 \mathrm{~cm}$. Smaller nodules are only clinically followed up every six months, as well as in patients younger than 25 . Removal is indicated only in cases of rapid growth and in women older than 35 . $^{7}$

In the case reported, removal of the nodules was indicated due to their dimensions. Because patients diagnosed with complex FAs are 3.1 times more likely to develop invasive breast cancer and because the risk remains high for at least 20 years after diagnosis, ${ }^{1,6}$ a longitudinal follow-up of the patient with ultrasonography was indicated every six months.

\section{FINAL CONSIDERATIONS}

This present bibliometric literature review has allowed us to discuss on 160 articles, which addressed the theme of complex fibroadenoma on different occasions. From the characterization and analysis of the above-cited articles, evidence states that there are gaps in the production of knowledge on FAs, because there are only a few studies investigating the theme in depth.

By analyzing the bibliometric aspects of scientific production, health care professionals and researchers can understand the characteristics of the published articles. Moreover, further investigations and new studies are extremely necessary as complex FA is still widely unknown by general practitioners in the medical practice.

Clinical case study facilitates a better understanding of complex FAs in various contexts, such as clinical characteristics, imaging examinations, and histopathological aspects, which can help the health care professional to make the pathology diagnosis.

\section{ACKNOWLEDGMENTS}

First, we thank God, for always giving us opportunities, strength and courage to overcome all challenges. We also thank our advisor, Prof. Antonione Santos Bezerra Pinto, for the support, guidance, and friendship. Dr. Thiago Santos Lima Almendra, for the presentation and assistance of the case reported. Our parents, for all the support, patience, understanding, and for all the help in achieving our dreams. Our brothers, for always being present in our lives, supporting us and encouraging us in our academic activities. Our friends, for helping us and always being by our side, always, be it during studies, research, or leisure. And for all the people who, directly or indirectly, contributed to our work.

\section{AUTHORS' CONTRIBUTION}

A.C.: conceptualization, methodology, formal analysis, investigation, writing original draft.

G.S.: conceptualization, data curation, writing original draft, writing review \& editing.

P.Z.: conceptualization, data curation, writing original draft, writing review \& editing.

A.P.: supervision, project administration, formal analysis, writing review.

T.A.: supervision, project administration, formal analysis, writing review.

\section{REFERENCES}

1. DupontWD, Page DL, ParlFF, Vnencak-Jones CL, PlummerJr.WD, Rados MS, et al. Long-term risk of breast cancer in women with fibroadenoma. New Engl J Med [Internet]. 1994 [accessed on Sept. 13, 2019];331(1):10-5. Available at: https://www.ncbi.nlm.nih.gov/ pubmed/8202095 https://doi.org/10.1056/nejm199407073310103
2. Kuijper A, Mommers EC, van der Wall E, van Diest PJ. Histopathology of fibroadenoma of the breast. Am J Clin Pathol [Internet]. 2001 [accessed on Sept. 2, 2019];115(5):736-42. Available at:https://www.ncbi.nlm.nih.gov/pubmed/11345838 https://doi.org/10.1309/f523-fmjv-w886-3j38 
3. Pinto J, Aguiar AT, Duarte H, Vilaverde F, Rodrigues A, Krug JL. Simple and Complex Fibroadenomas. Are There Any Distinguishing Sonographic Features? J Ultrasound Med [Internet]. 2014 [accessed on Sept. 13, 2019];33(3):415-9. Available at: https://www.ncbi.nlm.nih.gov/pubmed/24567452 https://doi.org/10.7863/ultra.33.3.415

4. Ohashi R, Matsubara M, Watarai Y, Yanagihara K, Yamashita K, Tsuchiya S-I, et al. Cytological features of complex type fibroadenoma in comparison with non-complex type fibroadenoma. Breast Cancer [Internet]. 2016 [accessed on Sept. 2, 2019];23(5):724-31. Available at: https://www.ncbi.nlm.nih.gov/ pubmed/26249102 https://doi.org/10.1007/s12282-015-0632-9

5. Almeida ACO. Fibroadenomas Mamários - que entidade?: artigo de revisão [dissertation] [Internet]. Coimbra: Faculdade de Medicina, Universidade de Coimbra; 2015 [accessed on Sept. 17, 2019]. Available at: https:/estudogeral. uc.pt/bitstream/10316/31286/1/Trabalho\%20final\%20 6\%C2\%BAano_\%20Fibroadenomas\%20Mam\%C3\%Alrios.pdf

6. Sklair-Levy M, Sella T, Alweiss T, Craciun I, Libson E, Mally B. Incidence and Management of Complex Fibroadenomas. Am J Roentgenol [Internet]. 2008 [accessed on Sept. 11, 2019];190(1):214-8. Available at: https://www.ncbi.nlm.nih. gov/pubmed/18094314 https://doi.org/10.2214/ajr.07.2330

7. Nazário ACP, Rego MF, Oliveira VM. Nódulos benignos da mama: uma revisão dos diagnósticos diferenciais e conduta. Rev Bras GinecolObstet[Internet];2007[accessedonSept.17,2019];29(4):2119. Available at: http://www.scielo.br/scielo.php?pid=S0100$72032007000400008 \&$ script=sci_abstract\&tlng=pt https://doi. org/10.1590/S0100-72032007000400008

8. Pao ML. Concepts of information retrieval. Englewood: Libraries Unlimited; 1989. 285 p.

9. Lim WK, Ong CK, Tan J, Thike AA, Ng CC, Rajasegaran V, et al. Exome sequencing identifies highly recurrent MED12 somatic mutations in breast fibroadenoma. Nat Genet. 2014;46(8):87780. https://doi.org/10.1038/ng.3037

10. TanBY,AcsG,AppleSK,BadveS,BleiweissIJ,BrogiE,etal.Phyllodes tumours of the breast: a consensus review. Histopathology. 2016;68(1):5-21. https://dx.doi.org/10.1111\%2Fhis.12876

11. Delfino RJ, Smith C, West JG, Lin HJ, White E, Liao SY, et al. Breast cancer, passive and active cigarette smoking and N-acetyltransferase 2 genotype. Pharmacogenetics. 2000;10(5):461-9. https://doi.org/10.1097/00008571200007000-00009

12. Delfino RJ, Sinha R, Smith C, West J, White E, Lin HJ, et al. Breast cancer, heterocyclic aromatic amines from meat and N-acetyltransferase 2 genotype. Carcinogenesis. 2000;21(4):607-15. https://doi.org/10.1093/carcin/21.4.607

13. El-Wakeel H, Umpleby HC. Systematic review of fibroadenoma as a risk factor for breast cancer. Breast. 2003;12(5):302-7. https://doi.org/10.1016/s0960-9776(03)00123-1

14. Kabat GC, Jones JG, Olson N, Negassa A, Duggan C, Ginsberg M, et al. A multi-center prospective cohort study of benign breast disease and risk of subsequent breast cancer. Cancer Causes Control. 2010;21(6):821-8. https://doi.org/10.1007/s10552-010-9508-7
15. Yoshida M, Sekine S, Ogawa R, Yoshida H, Maeshima A, Kanai Y, et al. Frequent MED12 mutations in phyllodes tumours of the breast. Br J Cancer. 2015;112:1703-8. https://doi.org/10.1038/ bjc. 2015.116

16. Sawhney N, Garrahan N, Douglas-Jones AG, Williams ED. Epithelial--stromal interactions in tumors. A morphologic study of fibroepithelial tumors of the breast. Cancer. 1992;70(8):2115-20. https://doi.org/10.1002/10970142(19921015)70:8<2115::aid-cncr2820700818>3.0.co;2-k

17. Gordon PB, Gagnon FA, Lanzkowsky L. Solid Breast Masses Diagnosed as Fibroadenoma at Fine-Needle Aspiration Biopsy: Acceptable Rates of Growth at Long-term Follow-up. Radiology [Internet]. 2003 [accessed on Sept. 15, 2019];229(1):233-8. Available at: https://www.ncbi.nlm.nih.gov/pubmed/14519878 https://doi.org/10.1148/radiol.2291010282

18. Derossi DR, Ito K, Couto Filho JO, Bacchi CE. Avaliação da expressão da proteína bcl-2 no carcinoma de mama: estudo em punção aspirativa por agulha fina; correlação com grau histológico em espécimes cirúrgicos correspondentes. J Bras Patol Med Lab [Internet]. 2003 [accessed on Sept. 11, 2019];39(3):229-35. Available at: http://www.scielo.br/scielo.php?script=sci_arttext\&p $\mathrm{id}=$ S1676-24442003000300010 https://doi.org/10.1590/ S1676-24442003000300010

19. Darooei M, Khan F, Rehan M, Zubeda S, Jeyashanker E, Annapurna S, et al. Med12 somatic mutations encompassing exon 2 associated with benign breast fibroadenomas and not breast carcinoma in Indian women. J Cell Biochem [Internet]. 2018 [accessed on Mar. 3, 2019];120(1):182-91. Available at: https://doi.org/10.1002/jcb.27293

20. Stachs A, Stubert J, Reimer T, Hartmann S. Benign Breast Disease in Women. Dtsch Arztebl Int [Internet]. 2019 [accessed on Mar. 5, 2019];116(33-34):565-74. Available at: https://www.ncbi.nlm.nih.gov/pmc/articles/PMC6794703/ https://doi.org/10.3238\%2Farztebl.2019.0565

21. Roveda Junior D, Piatto S, Oliveira VM, Rinaldi JF, Ferreira CAP, Fleury ECF. Valores preditivos das categorias 3, 4 e 5 do Sistema DI-RADS em lesões mamárias noduláveis não-palpáveis avaliadas por mamografia, ultra-sonografia e ressonância magnética. Radiol Bras [Internet]. 2007 [accessed on Mar. 3, 2019];40(2):93-8. Available at: https://www.scielo.br/scielo. php?script $=$ sci_arttext\&pid $=$ S0100 -39842007000200006 https://doi.org/10.1590/S0100-39842007000200006

22. CaladoSS,Lima MCCA.Estudomorfológicodos fibroadenomas da mama: uma análise comparativa entre grupos etários. J Bras Patol Med Lab [Internet]. 2004 [accessed on Sept. 11, 2019];40(6):4119. Available at: http://www.scielo.br/scielo.php?pid=S167624442004000600009\&script=sci_abstract\&tlng=pt https://doi. org/10.1590/S1676-24442004000600009

23. Fleury EFC, Rinaldi JF, Piato S, Fleury JCV, Roveda Junior D. Appearance of breast masses on sonoelastography with special focus on the diagnosis of fibroadenomas. Eur Radiol [Internet]. 2009 [accessed on Sept. 11, 2019];19(6):1337-46. Available at: https://www.ncbi.nlm.nih.gov/pubmed/19159934 https://doi. org/10.1007/s00330-008-1285-2 